New Zealand journal of industrial relations, 1987, 12, 151-159

\title{
Holt and the establishment of arbitration: an Australian perspective
}

\author{
Stuart Macintyre*
}

'Even the argument that New Zealand has done something is not sufficient to satisfy me of the correctness of the present movement.'The speaker was Sir John Downer, a delegate to the final session of the Australian Federal Convention in 1898. The occasion was a debate on industrial arbitration, during which enthusiasts pointed repeatedly to the success of the New Zealand Industrial Conciliation and Arbitration Act of 1894. And the outcome was that by a narrow majority the Convention reversed its previous decisions and empowered the Commonwealth to make laws for "conciliation and arbitration for the prevention and settlement of industrial disputes extending beyond the limits of any one State.' (Victorian Government Printer, 1898, vol. 1, p. 187)

Sir John's conservative pique is understandable. New Zealand precedents exercised a pervasive influence on Australian public affairs in the closing years of the nineteenth century. From taming an obdurate upper house to busting up big estates, from tax reform to the enfranchisement of women, the Ballance and Seddon ministries furnished Australian progressives with a storehouse of precepts. When their opponents sought to spike such arguments by distinguishing New Zealand's circumstances from Australia's, they were unwittingly conceding the allure of the neighbouring colony: New Zealand was a smaller, more homogenous society with a surer climate and a less complex economy; or, as a New South Wales parliamentarian put it in 1900, in 'a simple little democracy' it was easy to 'set up a little utopia'. (Chan, 1971, p. 155)

Of course the traffic across the Tasman went in both directions. New Zealanders are perhaps more aware than Australians of the multiplicity of links between the Australasian colonies in the late nineteenth century: migration, investment, trade, overlapping labour markets, a shared cultural heritage and some common responses to their antipodean circumstances (Sinclair, 1987). Nor is it surprising that the two countries should have learned from each other's inititatives in public policy at this time since they worked with parallel political institutions and confronted broadly similar challenges. Their primary export sectors, which had brought rapid growth by marrying foreign capital to rich natural resources, had reached the limits of expansion within existing methods and relations of production. The need to restore profitability and restructure the economies provoked conflict between capital and labour that threatened to shatter the social and political fabric. The conflict was concentrated in the key industries where the stakes were highest and well-organised groups of employers met large combinations of workers - for the workforce employed in these industries were the most mobile and best able to pool their common experience. The New Zealand shearers' and miners' unions both affiliated to their Australian counterparts in the late 1880s; and the fateful maritime strike of 1890 , which triggered the turn to arbitration on both sides of the Tasman, spread to New Zealand in solidarity with Australian unionists. In similar fashion, the architects of arbitration exchanged information and ideas.

Arbitration was only one initiative among many developed in response to the crisis, but it stands out both because of its far-reaching effects and because it was new and peculiar to these two countries. With justifiable pride, Pember Reeves devoted the greater part of the second volume of his State experiments in Australia and New Zealand to the machinery he pioneered. No 
British, American or continental European account of the social laboratory of the south was complete without an appraisal of the arbitration system.

It has been observed that the inhabitants of the United Kingdom and the United States are particularly prone to misunderstand each other because they labour under the fateful illusion that they speak the same language. It may well be the same with New Zealanders' and Australians' joint experience of arbitration. I have already observed that the two systems emerged out of a common predicament. The statements of their progenitors reveal no significant differences of approach or purpose. The machinery, the procedures, the very structure and language of the statutes that established arbitration, display a remarkable similarity. Nevertheless, there are reasons for circumspection.

To begin with, the timing differed significantly. New Zealand introduced its arbitration system in 1894 when economic recovery was under way, and speedily made the system effective. The Australian colonies (from 1901, States) began more hesitantly in the 1890 s while still suffering from a contraction of economic activity - some settled for the less ambitious device of wage boards - and the central Commonwealth Arbitration Court, established in 1904, was circumscribed by restrictions on the federal jurisdiction. Second, New Zealand and Australia took divergent paths in rebuilding their economies, as the one intensified and the other modified the international division of labour. Refrigeration allowed New Zealand to develop new export industries and enter a new phase of growth as prosperity flowed from the farms and processing industries to the towns (Hawke, 1985, pp. 5-6). While Australia also diversified its farm production, greater attention was given to the protection and encouragement of secondary industry. The class configuration and political balance of each country differed accordingly. In New Zealand the farmers matched the influence of the urban bourgeoisie, whereas in Australia they formed a resentful a minority. In Australia the presence of an industrial working class was unmistakable, whereas in New Zealand, according to the Moariland Worker in 1912, 'if all the organised workers of New Zealand joined the Federation of Labor and decided to bring about the Revolution they couldn't do so, because they are only 10 per cent of the population:. (Olssen, 1981, p. 271) The Australian labour movement might not have aspired to such heights but by 1910 , when it enjoyed office federally and in three of the States, it clearly held the political initiative. New Zealand Labour had to wait until 1935 to form a government.

It may well be that the dominion capitalist countries are locked into a common trajectory which, in the end, will frustrate their efforts to control their destiny within the world economy (Ehrensaft and Armstrong, 1981). Certainly the events of the past decade have seen both Australia and New Zealand abandon many of the distinctive devices through which they used to believe that they could mould economic forces to national goals. But during the first part of the twentieth century it is apparent that the two countries drifted apart as they embarked on their different courses. Under these circumstances it would not be surprising if their common initiative in the field of industrial arbitration developed along different lines and had different consequences. It is surely significant that after the initial flurry of interest had produced a substantial literature on the industrial experiment in the Antipodes, few scholars over the next fifty years compared their arbitration systems.

James Holt's history of Compulsory arbitration in New Zealand therefore has an augmented value for the Australian reader. First of all, it offers a clear and systematic account of the establishment and operation of the New Zealand system for its first forty years. Second, it invites trans-Tasman comparisons. There is no Australian equivalent to Holt, though it is to be hoped that his exemplary general history will encourage one. Even so, it is possible to set aspects of the Australian experience against that of New Zealand, and in the following pages I shall concentrate on the formative period.

First there is the vexed question of origins. Vexed, because a dispute over paternity began even while the ink on the birth certificate was still wet. The two mettlesome claimants were Pember Reeves and the South Australian Charles Kingston. Both were lawyers-turnedpoliticians and advanced liberals who advocated arbitration in the aftermath of the 1890 maritime strike. Both drafted bills after reviewing the available international precedents. Kingston late in 1890 and Reeves shortly afterwards. Holt notes that Reeves was sent a copy of Kingston's bill in March 1891 (it was in any case published as an appendix to the Report of the New South Wales Royal Commission on Strikes) but credits Reeves with being the "principal author' of the New Zealand legislation (Holt, 1986, pp. 17, 24, 31). Here he follows Reeves' biographer, Keith Sinclair, who also acknowledged the debt Reeves owed to Kingston among others, but judged that 'Reeves did much of the drafting himself of the bill that he circulated in 1891 (Sinclair, 1965, p. 151). 
This judgement is based partly on circumstantial evidence and partly on Reeves' own testimony, but predominantly it relies on a comparison of the provisions of the South Australian and New Zealand statutes (which Reeves himself had conducted in State experiments in Australia and New Zealand). Sinclair and Holt draw attention to the limitations and deficiencies of Kingston's scheme that were overcome in the New Zealand version. Most of these comparisons, however, rest on a confusion between Kingston's original bill and the statute that was finally enacted in heavily amended form by the South Australian parliament in 1894. In title, form, organisation and contents the original bill bears a close resemblance to its New Zealand counterpart. A recent analysis of the provisions of the bill that Kingston presented for the first time to the South Australian House of Assembly on 12 December 1890 reveals, convincingly in my opinion, that it was the earliest version of the classical form of the Australasian compulsory arbitration presented to any parliament (Mitchell 1987). Kingston certainly thought so - on several occasions he expressed his resentment that Reeves had not properly acknowledged the full extent of his obligation - and some historians have subsequently recognised his claim to paternity (Ko, 1926, pp. 147-8; Portus, 1958, pp. 103-4; Chan, 1971, p. 53; see also Spence, 1909. pp. 476-6; Sutcliffe, 1967, p. 149). Reeves' principal achievement perhaps lay in the successful passage and implementation of the scheme, for by the turn of the century it had become commonplace, even in South Australia, for advocates of arbitration to refer to the New Zealand system'. The last work is best left with Alfred Deakin, who, on this as on so many other occasions, found a formula to satisfy the honour of both parties. Speaking during the debate on the Commonwealth Conciliation and Arbitration Bill, and with the prickly Kingston sitting immediately behind him, he put it thus:

The New Zealand Bill, introduced in 1894, and modelled closely on the lines of the South Australian proposal, took a more ambitious flight, and, in happier circumstances, achieved a greater success. It was amended from time to time, until 1900, when it was consolidated, and now represents what will always remain one of the most remarkable pieces of practical legislation which Australia or any other country has ever witnessed, for which Mr Pember Reeves deserves the highest honour (Commonwealth Parliamentary Debates, 1903, p. 2866).

If this adjudication of the paternity dispute is accepted, there are more important issues arising from the establishment of arbitration that a comparative perspective can help to elucidate. Tony Simpson (1987) observes that Holt's account of the origins of arbitration in New Zealand is restricted by its teleological approach ('it seems ... to emerge as if from a chrysalis') and the hermetic effect of its narrative structure ('no consistent pattern of meaning emerges from it which relates it to the broader political scene'). The same difficulties bedevil existing Australian accounts of the creation of arbitration within a state or federal setting they too tell a story whose outcome is anticipated from the beginning. But when the Australian and New Zealand experiences are juxtaposed, neother the context nor the outcome can be so easily assumed: while a sample of one is difficult to interpret, a second specimen permits the identification of variables. Above all, a comparative approach makes it possible to pose two complementary questions: why did these two countries, but not others, adopt this distinctive method of regulating industrial relations, and why was it adopted more readily in the one than the other?

Holt's opening chapter on 'Origins' deals rather cursorily with the explanations advanced by contemporaries for the innovation:

Strikes and lockouts, they argued, were intolerable methods of settling differences between employers and employees. They ruined businesses and brought misery to workingmen and their families. They imposed great burdens on innocent third parties, such as workers in related industries, and consumers. They were a barbaric method for adult men and women to settle their difference in civilised countries (Holt, 1986, p. 15).

Such claims were advanced in Australia as well as New Zealand, but their intellectual provenance lay abroad in the co-called 'new liberalism' that shifted the relationship between the state and the citizen. Since the earlier liberalism that enshrined freedom from state interference had failed manifestly to solve problems of poverty and inequality that threatened to poison public life, the new generation of liberals asserted the need for collectivist measures that would enhance the capacity of citizens. These ideas took on a particular salience in Australia and New Zealand at the time of the Maritime Strike, but I am not convinced that a single event, even one of this magnitude, explains such a radical departure. Rather, it is necessary to explain why the older liberalism, with its insistence that the state should leave 
industrial relations to be resolved by free and responsible parties, should have yielded so quickly to the new liberalism with its enlarged conception of state responsibility. In New Zealand the ease of this transition is especially striking. '[T] he right of private persons to manage their own business without State interference ceases upon their conduct becoming an injustice to others or an inconvenience to the nation.' (Reeves, 1969, vol. 2, p. 165) With no trace of hesitation, Reeves moves here from Mill's careful qualification of the freedom of the individual to the loosest of formulations of a quite different consideration, the mere convenience of a collective abstraction that he called the nation.

So how are we to explain such a ready acceptance of the new claims? I would suggest that it sprang from a particular configuration of circumstances within the historical experience of these white settler societies. After their recent and chastening misfortunes with world trading conditions, they had begun to restructure their primary export sectors. But the domestic sectors, which provided a livelihood for the majority, remained highly sensitive to fluctuations in the volume and price of the primary export staples. The desire to stabilise the domestic economy and protect it from sudden external shocks had political as well as economic impulses. For in the absence of such correctives, there was the prospect of recurrent contractions of employers and wage-earners and endemic political instability. Since the settler societies had long since opted for democracy, the pressure for state intervention was direct and insistent. There was already an extensive pattern of state involvement in the colonial economies through capital formation, operation of public enterprises and the provision of services. Furthermore, a quickening sense of national destiny fostered a willingness to fashion new institutions.

Beyond the immediate and avowed object of arbitration, to enforce industrial peace, there were far-reaching expectations and assumptions about how arbitration would foster an environment in which industrial peace would be possible. As Holt observes, the New Zealand Arbitration Act encouraged the formation of trade unions for precisely this reason; so too did the subsequent Australian arbitration legislation (though not the wage board system, which provided for direct representation of employers and employees). The provision for union registration obviated the issue that had occasioned the Maritime Strike in the first place and would remain a major cause of industrial conflict elsewhere - the refusal of employers to recognise and negotiate with unions. And at the same time that it gave recognition to unions, arbitration imposed an extensive control over their rules, procedures and the legitimate ambit of their activities.

The economic rationale of arbitration was that it provided a mechanism, as well as a justification, for stabilising price and income movements as they spread from the relatively open to the relatively closed sectors of the colonial economies. (Scherer, 1983) Another and equally fundamental aspect needs to be recognised. When liberals tackled the problem of adjusting public policy to the new economic circumstances, they were as much concerned with the wider social consequences as they were with the immediate problem of industrial unrest. Unemployment and poverty, wage cuts, deskilling and the substitution of female and juvenile labour for male labour - these were some of the manifestations of what became known as the social problem'. Liberal and humanitarian reformers were increasingly aware that this social problem had its basis in the commodification of labour; they had no intention of preventing the buying and selling of human labour-power, but they did want to impose limits on the labour market that would check abuses and restore a proper harmony between master and man. As Simpson observes, there was a close proximity in New Zealand between the initial legislative attempts to limit hours of employment, regulate factory conditions, prohibit outwork and check sweating, and the subsequent adoption of arbitration. The same connection is apparent in Victoria where the creation of wage boards arose directly from the manifest failure of earlier factory acts, and in Tasmania where a royal commission into sweating led again to the establishment of wage boards. Arbitration was more ambitious in scope than the wage board approach, but it was also the most effective and far-reaching response to these concerns since it went directly to the problem of regulating employment practices to safeguard and status and earning capacity of male wage-earners (Macintyre, 1985, chap. 3)

Holt says little of this aspect of arbitration but recent feminist scholarship has stressed its importance in Australia. There are particular studies showing how arbitration served to reestablish gender boundaries in the workplace and reinforce patriarchal authority (Ryan. 1984; Lee, 1987). More generally, it has been argued that arbitration had lasting consequences because of the way it made the wage the pivotal instrument of social welfare. After the living wage became the principal means of meeting the material needs of the working-class family. 
all other forms of public assistance were designed as limited and supplementary measures. The old-age pension cushioned the last years of those who had retired from the workforce; invalid pensions and worker's compensation gave limited protection from sickness or accident; the maternity benefit met the additional expenses incurred in childbirth: some measure of sustenance of charity was provided to the dependants of unemployed workers. But all of these measures were premised on the assumption that there was a male breadwinner providing for the typical income unit. and the primary object of Australian public policy up to the 1940s was to make that assumption good (Macintyre, 1986a).

In summary, the attraction of arbitration was that it met the particular needs of the settler societies in a way that was consistent with their economic circumstances and their political and social predilections. Why, then. was the device accepted more readily in New Zealand than in Australia? On this question Holt's account has particular interest for the Australian reader. The contrast is striking: Reeves bill was introduced into parliament in 1892, enacted in 1894. and fully operational by 1896 - five years before the first Australian Arbitration Court opened its doors. The difference in timing reflects a difference of political conditions. In New Zealand arbitration was the work of a Liberal ministry that enjoyed broad support, including the support of the trade unions; accordingly, the Government was able to force the measure through the obstructionist upper house and then remove its deficiencies by the speedy passage of amending legislation as soon as they became apparent. In every one of these respects Australia differed: its established political parties were already under challenge from the Labor Party: its second chambers remained obdurate, and its comparative lack of political stability meant that there was seldom the opportunity to make good the defects of the early tribunals.

The role of the Labor Party requires closer attention. The orthodox interpretation emphasises the labour movement's support for arbitration. and pays particular attention to the leverage that the leverage that the infant Labor Party was able to exert on the other parties through its strategy of 'support in return for concessions'. P.G. Macarthy has given an influential exposition of this view:

Fortuituosly, party alignments and personality rivalries enabled the new labour parties to exercise influence disproportionately to their numbers by capitalising on their strategic position in holding the balance of power in colonial, state and commonwealth parliaments (Macarthy. 1967a. p. 74).

Purely on the Australian evidence, this explanation is open to challenge. It exaggerates both the commitment to arbitration within the labour movement and the influence that the movement wielded. These objections apply with particular force in South Australia and Victoria, where Labor remained under the wing of the liberals until after the turn of the century; in Western Australia, where arbitration was enacted in 1900 before Labor made its parliamentary debut; and in Tasmania, where Labor still remained a negligible force. In New South Wales, Queensland and the Commonwealth, the minimum requirements of the hypothesis - an independent Labor Party with significant political strength - were at least in evidence, but even there its validity is still doubtful. Labor held the balance of power in New South Wales from 1891 but had to wait until 1901 for a non-Labor administration to introduce compulsory arbitration. In Queensland the wait was even more protracted and the best that Labor could achieve until it won office itself in 1915 was wage boards. And in the Commonwealth parliament the two non-Labor parties called Labor's bluff, so that it was a coalition drawn from them both that framed the measure finally adopted in 1904 (Macintyre, 1987).

My reading of the evidence is that while Labor pressed for arbitration with increasing unanimity and ardour from the turn of the century, it was the non-Labor forces that initiated the measure along lines and according to a timetable that they controlled. As in New Zealand, the most ambitious schemes were devised by liberal enthusiasts. The advent of Labor arguably weakened, rather than assisted their efforts since it turned working-class members of parliament who might otherwise have assisted them into political opponents and left a weakened liberal rump that was forced to take up an increasingly unsympathetic stance. That is to say, insofar as arbitration was meant to mediate class antagonisms in industry, it was more likely to win acceptance where class antagonisms had not become the organising principle of political life. I put forward this suggestion on the basis of the New Zealand experience and there is some

1 This interpretation (see Macarthy bottom of first page 1967 b: Rickard, 1976) supplanted the earlier view of Brian Fitzpatrick that arbitration had been imposed on the workers by employers and conservative politicians (Fitzpatrick. 1941, pp. 228-9). 
Australian evidence to support it. In Victoria, where liberalism was historically strong, the trade unions established a United Liberal and Labor Party to contest the 1894 elections as an advanced wing of the mainstream Liberal majority; it endorsed candidates both from its own ranks and from among sympathetic Liberals, and 18 of them were successful. The unions were rewarded by the creation of the first wage boards in 1896; but when they subsequently broke away to form a separate Labor Party, their call for arbitration went unanswered.

The protracted gestation of arbitration and the circumstances of its political contestation are thus thrown into bold relief by the New Zealand comparison. But for an explanation of these contrasts we need to go further. Bearing in mind the argument made earlier about the social and economic aspirations that arbitration was intended to serve, it is now necessary to consider the alignment of class interests in the two countries and the patterns of their political articulation.

Holt sketches neatly the balance of forces that he sees operating in New Zealand:

The essence of the political situation which allowed compulsory arbitration to become law in New Zealand in 1894 was that the unions, being industrially weak, lacked the will to oppose it, while the employers, being politically weak, lacked the power to prevent it (Holt. 1986, p. 25).

Much of this is uncontentious. The weakness of the unions in the immediate aftermath of the Maritime Strike was such that they were unlikely to spurn the lifeline that Reeves threw them. Correspondingly, the employers were loath to give up their freedom of action at a time when they could unilaterally prescribe wages and conditions. But in what sense were they politically weak? Holt suggests three aspects. First and most obviously, most of them were aligned with the political opposition and commanded limited influence within the ruling Liberal administration. Second, they lacked organisation. In this respect their victory in 1890 had been too complete, for they had failed to maintain a peak body and consequently were unable to mobilise the popular support that might have averted the Liberal victory in the election of 1893. Third, there was a conspicuous lack of unity between urban and rural employers. The farmers, who were well represented in the Liberal ministry, were placated by the reassurance that arbitration would be confined to the towns and simply left their urban counterparts to their fate. (Holt, 1986, pp. 23-5, 45-9)

Much Australian writing on union and employer attitudes to the introduction of arbitration runs on similar lines. Macarthy and Rickard have described Australian unionists turning to arbitration as a means of securing outcomes that they could not obtain by traditional bargaining procedures. They portray the employers as generally opposed to arbitration in the flush of their victory, but disunited and consequently ineffective in their opposition to the measure. In particular, they explain how some employers came to see advantages in the policy of New Protection that linked wage regulation and tariffs, and thus offered them protection against imports as well as cost-cutting domestic competitors. ${ }^{2}$

Here already is an interesting contrast with New Zealand: in one country it was the farmers whose potential opposition was neutralised by exemption, in the other it was the manufacturers whose acceptance was bought by protection. But more recent work suggests the need for further qualifications. Employers played a much more active role than is commonly allowed, for arbitration provided a stimulus for the creation of new organisations which embarked on a new scale of industrial and political activity. The process can be observed at the turn of the century when compulsory arbitration was introduced in New South Wales and Western Australia, the Victorian wage boards were extended and there was the imminent creation of the Commonwealth Arbitration Court. In response to these developments, the Victorian Employers' Federation was established in 1902. the New South Wales Employers' Federation in 1903 and the Queensland counterpart in 1904, when representatives from these three States as well as South Australia formed a Central Council of Employers of Australia to co-ordinate their efforts (Plowman 1986).

The new bodies had a decisive impact on non-Labor politics - indeed George Reid, the leader of the federal free-trade party, made an immediate bid for their support by launching his celebrated 1905 crusade to exterminate the socialist tiger. Though Deakin tried to maintain the independence of his protectionist liberals, he came under increasing pressure and in 1909

2 In fact the statutory link was broken when the High Court struck down the provision of the Excise Tariff Act on which Higgins based his Harvester Judgement, but the connection between protection and maintenance of the basic wage remained a political convention for the next half-century. 
accepted the inevitable fusion of the non-Labor forces. Liberalism was spent as an autonomous force in Australian politics, its capacity to innovate in the field of industrial relations at an end. In their immediate intention to resist or restrict arl itration, the employers also had considerable success. The New South Wales Court was L.amstrung by decisions handed down by the Supreme Court in response to actions brought by the employers. Its Western Australian counterpart was similarly paralysed. At the federal level the employers saw off Labor's arbitration proposals, secured the more limited legislation of the non-Labor coalition, and thereafter cramped the efficacy of the Court by a series of appeals to the High Court. Yet by this time the Australian employers had moved from their earlier rejection of arbitration to a more flexible strategy of containment which was conditional on its conditional acceptance. This became apparent in the period of sturm und drang which raged on both sides of the Tasman on the eve of the First World War.

There are clear similarities in the circumstances that produced the upsurge of labour militancy. Revived economic growth and an upward movement of prices created new wage pressures, especially among the less skilled and lower paid workers. The tempo of economic change, the erosion of established work practices and the imposition of new forms of work discipline all fostered a new militancy, which again was particularly pronounced in industries employing large groups of manual wage-earners. Under these circumstances the preference for collective bargaining. and the impatience with the delays and constraints of arbitration, spilled over into bitter and protracted disputes. Holt describes the wave of strikes that began in New Zealand in 1906 and lasted until 1913. In Australia the first major stoppage occurred at Broken Hill in 1909; over the next four years the turmoil extended to the New South Wales coalminers and ironworkers, transport workers in Queensland and Western Australia, the sugar workers of northern Queensland and finally the New South Wales gasworkers. All of these disputes followed a similar pattern of confrontation between pickets and police lasting many weeks until one side yielded reluctantly to the other (Macintyre, 1986b, pp. 113-21).

These disputes constituted an unprecedented test of arbitration in Australia as well as New Zealand. The difference was that New Zealand's Arbitration Act had been operating successfully for more than a decade before the 'Red Feds' posed a challenge to the Court with their policy of cancelling registration to replace compulsory arbitration by collective bargaining. Holt's narrative of the prior period of industrial peace shows how arbitration had been made to work in ways that went considerably beyond its original charter: 'The Arbitration Court had become a tribunal charged not only with resolving conflict but with fixing minimum wages. maximum hours and conditions of employment, in ever-growing areas of the private sector (Holt, 1986, p. 53). It did not always work to the satisfaction of all parties but it commanded acceptance: by international standards New Zealand was indeed a land without strikes. Holt also identifies the means whereby the Court coped with the challenge issued by the 'Red Fed' unions, notably the anti-strike provisions introduced in the 1908 amending legislation and the willingness to recognise alternative unions. Ultimately, Holt argues, the episode reinforced the legitimacy of arbitration and helped reconcile employers to it.

In Australia the prospects were much less propitious. Arbitration was still a new and imperfect instrument, and many unions and employers had still to be convinced of its benefits. The jurisdiction of the Commonwealth Arbitration Court was circumscribed as a result of a series of High Court decisions, and Higgins' celebrated Harvester Judgement had been struck down to the chagrin of the labour movement.

Some of the most dramatic confrontations were not strikes but lockouts, as in the Broken Hill dispute, or arose from action taken against union members, as with the Brisbane transport workers whose victimisation triggered a general strike. In both of these cases decisions in favour of the unions handed down by Higgins as president of the Commonwealth Arbitration Court were challenged by the employers and set aside; in these cases, as in others, conservative State governments invoked discriminatory powers to override arbitral procedures and victimise unionists.

In the light of episodes such as these it seemed clear that the employers' acceptance of arbitration was merely expedient. They were prepared to accept the decisions of State or federal tribunals when it suited them and to condemn strikers for defying these tribunals; but they felt no obligation to accept decisions that went against them. The unions exhibited the same attitude. The very basis of the new province for law and order seemed in doubt. Meanwhile the manifest failure of Labor governments to satisfy the expectations of unionists opened a breach between the political and industrial wings of the labour movement, expressed in the popular rhyme: 
I know the Arbitration Act

As a sailor knows his 'riggins'

So if you want a small advance

Ill talk to Justice 'iggins

Bang me into Parliament Bump me any way

Bang me into Parliament On next election day.

Even so, arbitration survived. It survived as something rather different from what its founders had intended - a mechanism for preventing industrial conflict - but it survived nevertheless. The reasons for its survival have nowhere to my knowledge been adequately explained, but as a first step we urgently need a narrative as clear and informative as that written by James Holt for New Zealand.

\section{References}

Chan K (1971) The politics of compulsory arbitration in Australia 1890-1910 PhD thesis, University of Sydney.

Ehrensaft P, Armstrong W (1981) The formation of dominion capitalism: economic truncation and class structure. In Moscovitch A. Drover G (Ed) Equality Toronto University Press.

Fitzpatrick B (1941) The British Empire in Australia 2nd edn Melbourne University Press.

Hawke G (1985) The making of New Zealand. An economic history Cambridge University Press.

Holt J (1986) Compulsory arbitration in New Zealand. The first forty years Auckland University Press.

Ko T (1926) Governmental methods of adjusting labor disputes in North America and Australasia New York, Columbia University Press.

Lee J (1987) A redivision of labour: Victoria`s Wages Boards in action, 1896-1903 Historical Studies 22 (88): 352-72.

Macarthy (1967a) Labour and the living wage, 1890-1910 Australian Journal of Politics and History 13(1): 68-89.

Macarthy (1967b) The Harvester Judgement: An historical assessment PhD thesis, Australian National University.

Macintyre S (1985) Winners and losers. The pursuit of social justice in Australian history Sydney, Allen and Unwin.

Macintyre (1986a) In Dawson D (Ed) Blast budge or bypass: towards a social democratic Australia Canberra, Academy of the Social Sciences in Australia.

Macintyre S (1986b) The Oxford History of Australia. Vol. 4 The succeeding age 1901-1942 Melbourne, Oxford University Press.

Macintyre S (1987) The politics of the establishment of arbitration. Paper presented at the Foundations of Arbitration Conference, University of Melbourne, 25-6 May 1987.

Mitchell R (1987)State systems of industrial conciliation and arbitration in England: antecedents of the Australasian model. Paper presented Foundations of Arbitration Conference. University of Melbourne, 25-6 May 1987.

Olssen E (1981) Towards a new society. In Oliver W H (Ed) The Oxford History of New Zealand Wellington, Oxford University Press.

Plowman D (1986) Employers and compulsory Arbitration: the Higgins era 1907-1920 Journal of Industrial Relations 28(4): 588-609. 
Portus J H (1958) The development of Australian trade unionism Melbourne, University Press.

Rickard J (1976) Class and politics. New South Wales, Victoria and the early Commonwealth Canberra, ANU Press.

Ryan E (1985) Two-thirds of a man. Women and arbitration in New South Wales 1902-8 Sydney. Hale and Iremonger.

Scherer P (1983) Nature of the Australian industrial relations system: a form of state syndicalism? In Hancock K. Sano Y, Chapman B. Fayle P (Ed) Japanese and Australian labour markets: A comparative study Canberra, Australian-Japan Research Centre.

Simpson T (1987) The Holt narrative and the industrial relations agenda New Zealand journal of industrial relations (this issue).

Sinclair K (1965) William Pember Reeves. New Zealand Fabian Oxford. Clarendon Press.

Sinclair K (1987) (Ed) Tasman relations. New Zealand and Australia 1788-1988 Auckland University Press.

Spence W G (1909) Australia's awakening Sydney, The Worker.

Sutcliffe J (1967) A history of trade unionism in Australia 2nd edn Melbourne, Macmillan.

Victorian Government Printer (1898) Official record of the debates of the Australasian Federal Convention, vol. 1. 